\title{
SIMULATION VERIFICATION OF BALANCING SYSTEM BASED ON NUMBER OF CELLS
}

\author{
Marek Šimčák*, Matúš Danko \\ Department of Mechatronics and Electronics, Faculty of Electrical Engineering and Information Technology, \\ University of Zilina, Zilina, Slovakia \\ *E-mail of corresponding author: marek.simcak@feit.uniza.sk
}

\section{Resume}

This paper deals with the simulation verification of balancing systems with different numbers of batteries. There is a simulation model of the battery with adjustable inputs and a simulation model of flyback converter. These components are interconnected and controlled externally to ensure balancing of individual cells. The batteries are connected in series and a flyback converter is connected to each battery. The outputs of these inverters are connected to the output of all the batteries. So, one can say that this balancing system is designed to lighten the charger. The results of the simulations show the voltage, current and State of Charge ( $\mathrm{SoC})$ of the batteries. Simulation models are presented in diagrams. These models were created in the PLECS environment.

\section{Article info}

Received 23 November 2020

Accepted 23 December 2020

Online 23 June 2021

\section{Keywords:}

battery management system, $\mathrm{LiFePO} 4$,

R2C2 battery model,

battery,

flyback converter,

flyback topology,

balancing system

\section{Introduction}

This article is motivated by researching the battery systems and improving battery performance. Capacity, durability and efficiency are essential features, not only of battery systems but of many electronic systems, as well. This article discusses how to manage and protect the energy stored in the battery. The highvoltage batteries often suffer from being connected in series to achieve the higher voltage. This connection causes a disproportionate capacity in the batteries. This capacity difference results in overcharging and over-discharging the individual battery cells. These inequalities arise during the production of those cells. Based on this knowledge, the battery management system is being examined. This battery management has three basic features: monitoring part, protective part and communication part. The monitoring part is designed to measure voltages, currents and temperature. Based on these measured values, the balancing system is controlled. The balancing system has the task of balancing the voltage levels of the individual cells. This avoids overcharging and overdischrging of the individual battery cells. The balancing is divided to two basic topologies: active balancing and passive balancing. The passive balancing system consists of converting the excess energy of the individual cells into heat, which is generated by the transfer of electric current through the shunt resistance. This method is inefficient and is only used for the low-capacity batteries and lead-acid batteries without control. An active balancing system consists of transferring the power from the overcharged cell to the entire battery pack or from the battery pack to the weakest cell. These methods may be CELL-TOPACK, PACK-TO-CELL or CELL-TO-PACK-TO-CELL. The passive method has the CELL-TO-ZERO topology. The active balancing systems are divided according to the energy transfer and storage element used. They are divided into capacitor topologies, inductor topologies or $\mathrm{DC} / \mathrm{DC}$ converter topologies. The protective part provides protection against overcharging, overdischarging or other unwanted conditions. The communication part provides communication between other control units, for example in an electric vehicle. This communication can be, for example, via CAN-BUS or other buses. All this is ensured by the battery management system. With increasing demands on batteries, this research is therefore potential in terms of research and the selection of a suitable topology for an active balancing system [1-4].

\section{The battery model}

The simulated model of the selected battery is shown in Figure 1. The model considers dynamics during the battery charging or discharging [1]. The individual $\mathrm{RC}$ components of the battery equivalent 


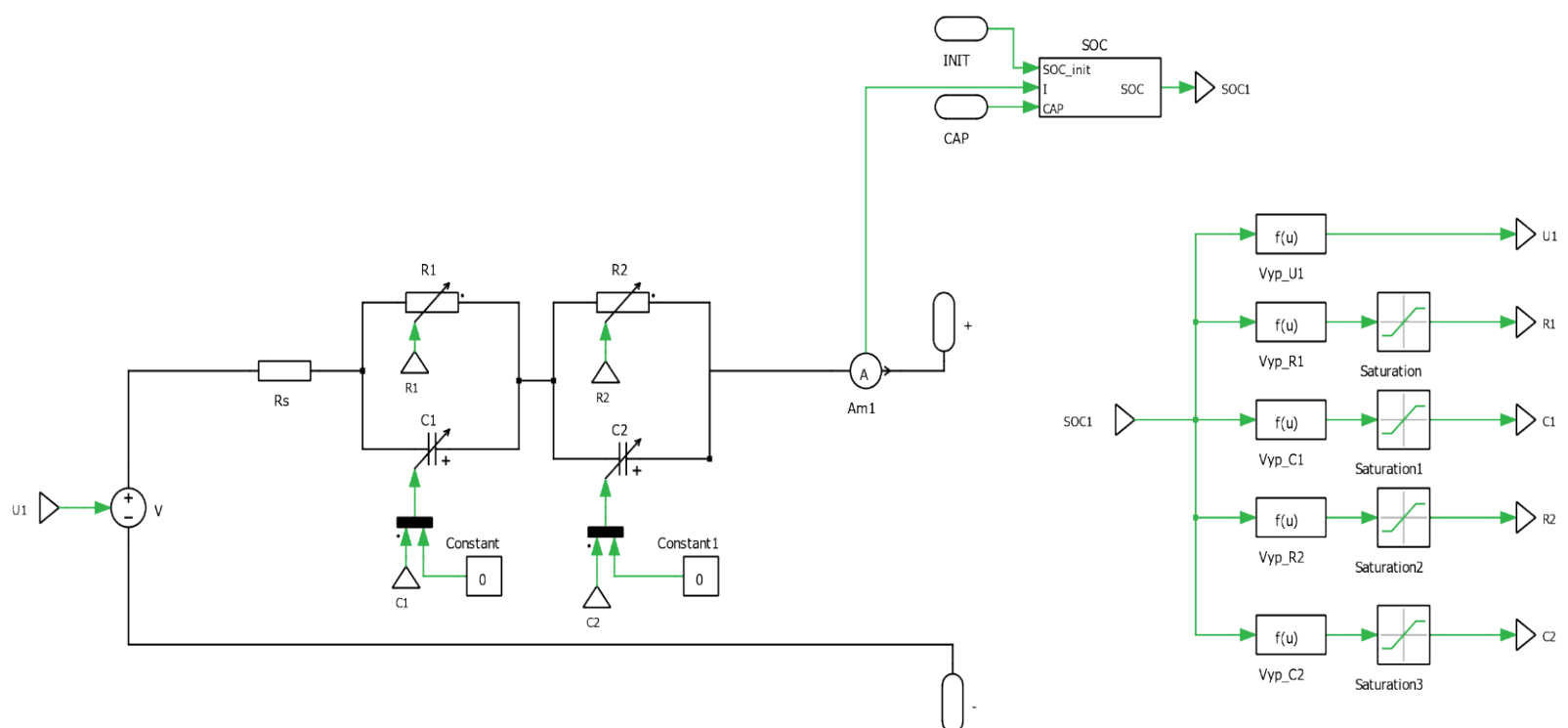

Figure 1 Equivalent battery scheme

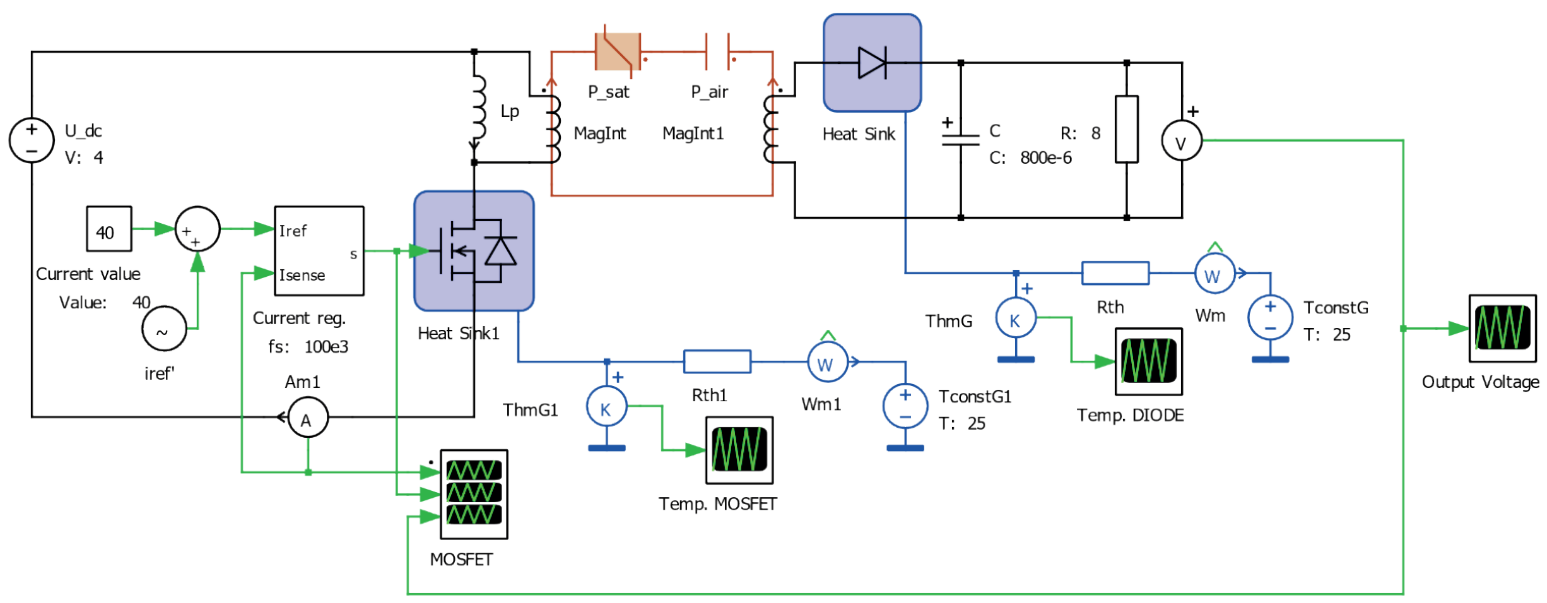

Figure 2 Model of the flyback converter controlled by the primary side current

circuit were determined from the results of laboratory battery measurements [1-4]. This battery simulation model can calculate the SoC by the Coulomb counting method. This is R2C2 equivalent battery model [5-10].

Functions blocks consist of calculation functions identified based on [11-13]:

$$
\begin{aligned}
& U_{1}=-1.031 e^{-35 u}+3.685+0.2156 u-0.1178 u^{3}, \\
& R_{1}=0.3208 e^{-29.14 u}+0.0745, \\
& C_{1}=-752.9 e^{-13.51 u}+703.6, \\
& R_{2}=6.603 e^{-155 u}+0.4984, \\
& C_{2}=-6.056 e^{-27.12 u}+4475 .
\end{aligned}
$$

\section{The flyback converter}

The topologies best suited for battery applications include the flyback converter topology. This is determined by its main advantages, one of which is galvanic isolation of input and output. Another advantage is that this flyback converter can be both an up and down converter. Based on these properties, a flyback converter was selected for simulation purposes. In the first case it was a flyback converter controlled by the input current (Figure 2) and in the second case a flyback converter controlled by the voltage of the secondary side of the high-frequency transformer (Figure 3). The disadvantage of this topology are the high losses in the transformer. These losses are compounded by the fact that this application is the low voltage one. The flyback converter has three base circuits: the primary side with the high frequency MOSFET or GaN transistor; the secondary side with the power diode or rectifier, while the third circuit is the magnetic circuit of the high-frequency transformer that provides the power transfer from the primary side to the secondary side of the high-frequency transformer. The flyback converter works blocking, i.e. when the transistor is turned on, energy is stored in the transformer core and when the transistor is turned off, this energy passes from the transformer core to the 


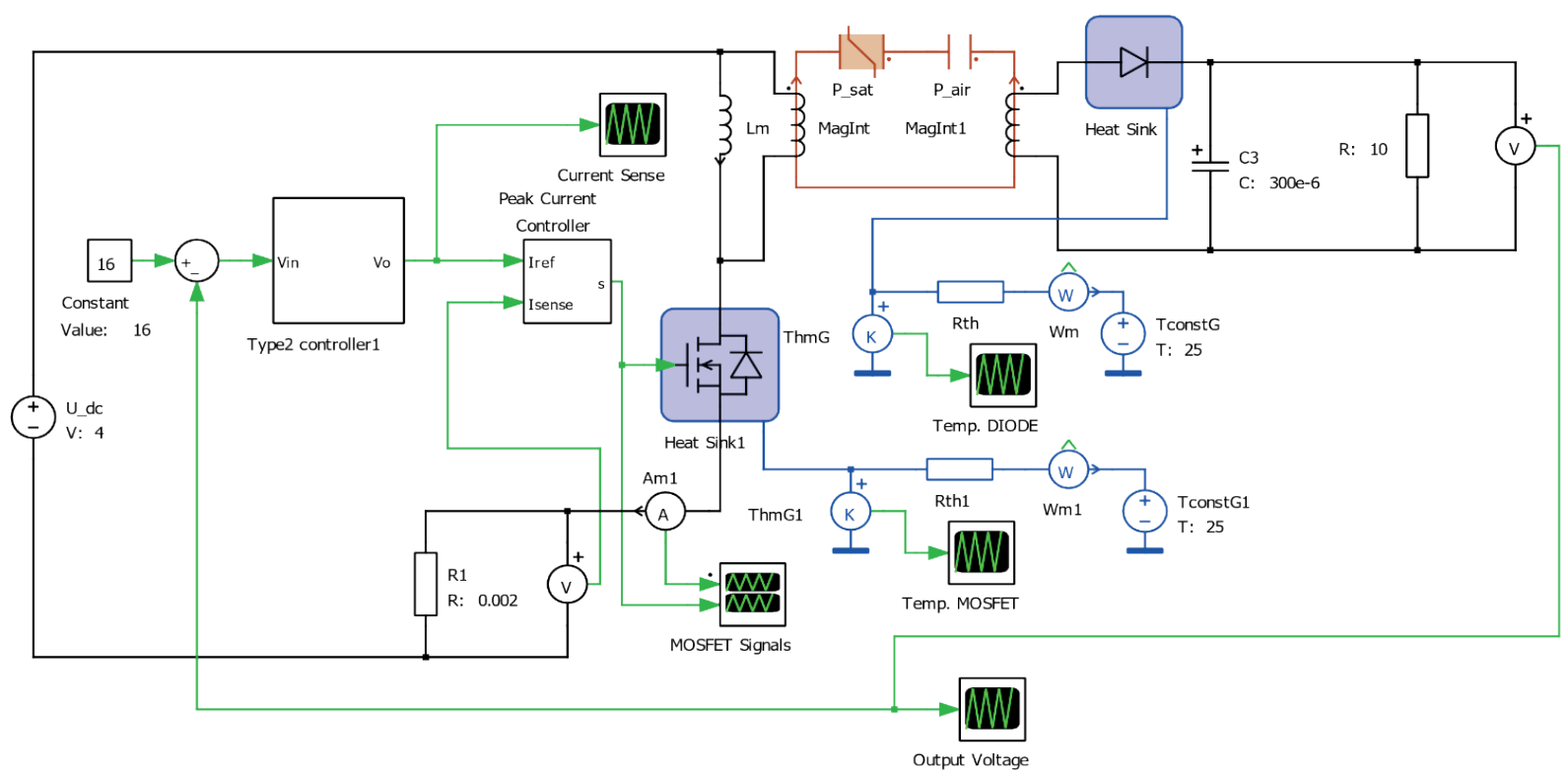

Figure 3 Model of thef lyback converter controlled by the secondary side voltage

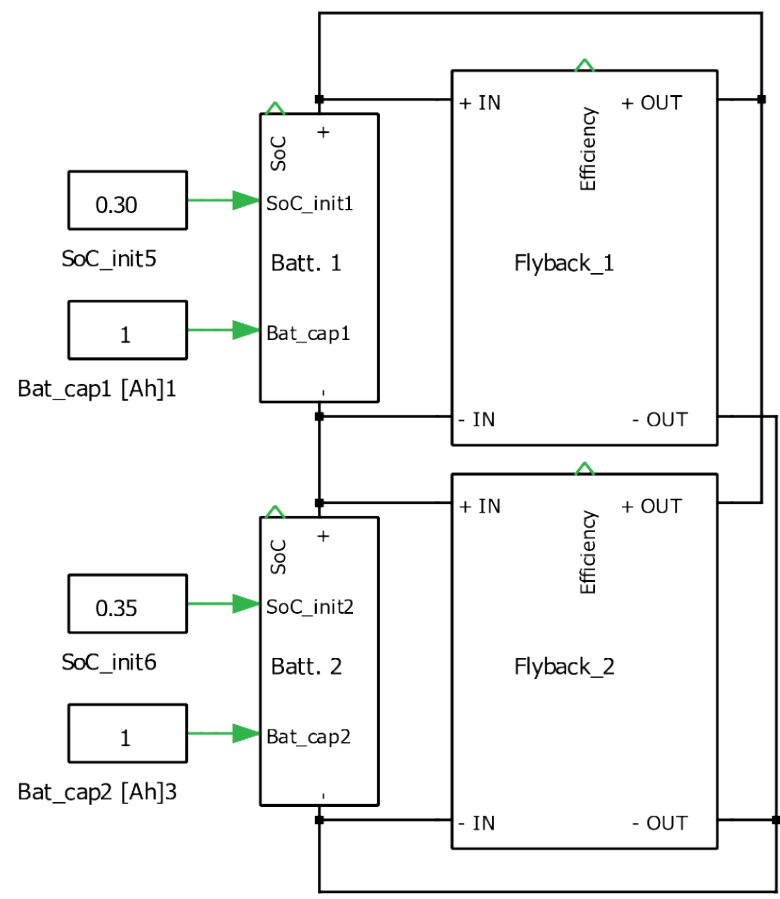

Figure 4 Simulation model of the BMS with 2 cells

secondary side of the transformer and to the output. This is especially true for high-frequency transformer of the flyback converter. Therefore, this topology has the great transformer requirements, mainly core saturation or thermal management [14-17].

In the PLECS environment, two simulation models of the flyback converter were created. One flyback converter is controlled by the primary side current value (Figure 2) and the other flyback converter is controlled by the secondary side voltage value (Figure 3 ). This model considers a replacement battery model at the primary side input. This is a voltage of $3-4 \mathrm{~V} \mathrm{DC}$. The output voltage is set by the transformer ratio. For the two-cell balancing system, this is a (3/15) ratio, while

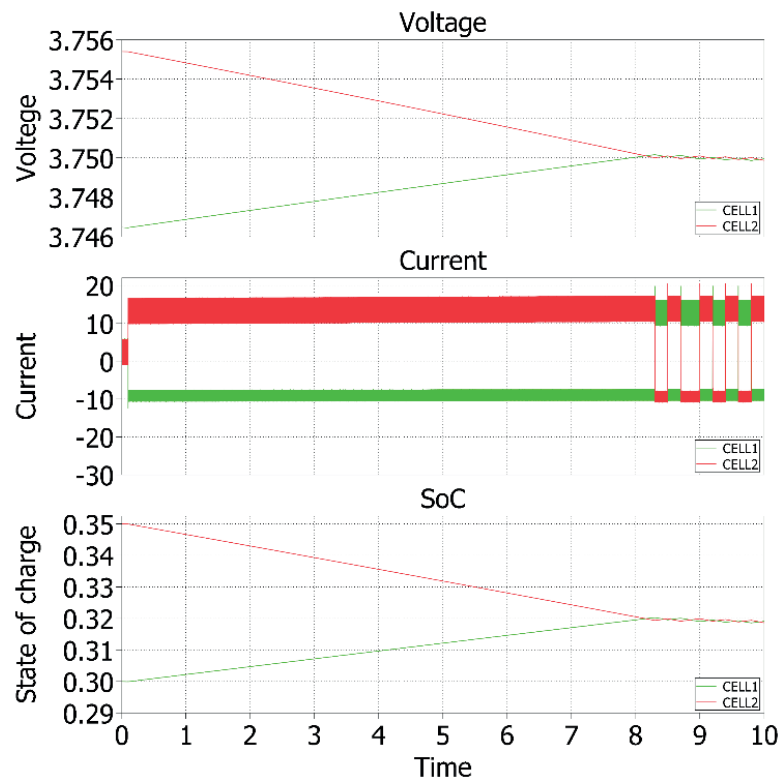

Figure 5 Waveforms of voltage [V], current [A] and state of charge [-] in terms of time [s]

for the four-cell balancing system, the ratio is $(2 / 21)$. Those ratios take into account the switching frequency of the MOSFET transistor and the saturation of the transformer core. Those values were calculated according to [18]. Thus, the output voltage in the balancing system will be twice the maximum voltage of one cell. Similarly, in a 4-cell balancing system, the output voltage will be four times the maximum cell voltage. Thermal power (blue) and magnetic circuit (brown) are simulated in this model, as well. Since it was intended to ensure the realistic behavior of simulation experiments, those flyback converters were implemented in a single block of the balancing system for the simple representation of the simulation block diagram. [19-20] 
Table 1 The flyback converter parameters for the 2-cell balancing system

\begin{tabular}{cc}
\hline parameter & value \\
\hline input voltage range & $3-4 \mathrm{~V}$ \\
output voltage & $8 \mathrm{~V}$ \\
output nominal current & $9 \mathrm{~A}$ \\
output nominal power & $75 \mathrm{~W}$ \\
switching frequency & $100 \mathrm{kHz}$ \\
required efficiency & $80 \%$ \\
\hline
\end{tabular}

\section{Balancing system with two cells}

As shown in Figure 4, the two-cell balancing system consists of the two battery models, two flyback converters and an evaluation circuit. Two constants enter the batteries: the battery capacity and the initial State of Charge (SoC). The flyback converters are connected by the primary side to a single cell and by the secondary side to the entire battery. Therefore, the secondary voltage value is twice as high for a two-cell balancing system. The evaluation section simply compares where the $\mathrm{SoC}$ value is greater and, based on that evaluation, a flyback converter is triggered for the cell where the $\mathrm{SoC}$ value is greater. In this way, the excess energy passes from the cell to the entire battery. This is the CELL-TOPACK topology. The flyback converter parameters for the 2-cell balancing systems are shown in Table 1 [21].

The results of the described balancing method are shown in the graph in Figure 5. This graph shows the three values that are the most important for monitoring the balancing systems. Those values are the state of charge, voltage and current (Figure 5) of each cell. For the high simulation requirements, especially for time, battery capacity values are only $1 \mathrm{Ah}$. This value is a fraction of the real value of the battery capacity. This was done to ensure that the simulation time is not an unnecessarily long. The monitored values would have the same courses, but they would be simulated faster [20-21].

Figure 5 shows the SoC balancing waveform. Here one can see that the initial SoC CELL1 is $30 \%$ and the SoC CELL2 is $25 \%$. In this course, one can see how the energy from CELL1 recharges CELL2. This works for up to 8.2 seconds. At 8.2 seconds, the $\mathrm{SoC}$ values get to a similar value. This ensures that the SoC values are kept at the same value. Thus, the balancing system has proven to work properly. However, one can see that the $\mathrm{SoC}$ value has a slight decrease. This decrease is caused by the efficiency of the flyback converters. This efficiency at such a low voltage is proportional to the size of the flyback converter current. From the given results one can say that there is no condition after which an unwanted condition may occur, such as under-voltage or over-voltage.

Figure 5 also shows the waveforms of balancing currents that compensate for the differences in the SoC on the cells. Here one can see how the CELL1 discharges via the flyback, thus charging both CELL1 and CELL2. After 8.2 seconds, the SoC reaches the same values and both flyback converters begin to switch. In this graph one can also see that one current is positive and one negative. This is caused by the current flow direction from and to the individual cells. When the current is positive, the cell discharges and when it is negative, the cell charges.

\section{$5 \quad$ Balancing system with four cells}

In contrast to the previous case, this system has the double number of batteries, as well as the double number of the flyback converters. This is a 4-battery system. As in the previous case, the flyback input of the inverters is connected to individual batteries and the output is connected to the entire battery. This determines that the inverter output must be four times the maximum voltage value of one battery. As in the previous case, the flyback block contains a trigger input, which is signaled by the evaluation part. This evaluation section aims to determine which cell has the highest SoC value. It determines which flyback converter will be started accordingly. This flyback converter transfers power from the strongest cell to the entire battery. This balancing system topology is CELLTO-PACK. The flyback converter parameters for the 4-cell balancing systems are shown in Table 2 [21].

In the first experiment with a 4-cell balancing system (Figure 6), the flyback converters were used that were correct according to the input current value. Initially, the SoC values of the batteries were around $25-40 \%$. Figure 7 shows the $\mathrm{SoC}$ waveforms, voltage and current of each cell in the flyback controlled to the input current value (Figure 2). This value can be seen in the current waveform, where the current is in the 40 A range. This is exactly the value to which these flyback converters are regulated. This value means that the course of the SoC and voltage balancing is constant. In 34 seconds, all the cells are balanced. Another feature that is needed to design a balancing system is efficiency. This value can be seen in the decrease in the SoC value after all the cells are balanced. At a current control value of $40 \mathrm{~A}$, one can see in Figures 7 and 8 that both the cell is discharged and charged at the same time, so the value of $40 \mathrm{~A}$, to which the flyback converter is set, this value will be lower by the secondary current 


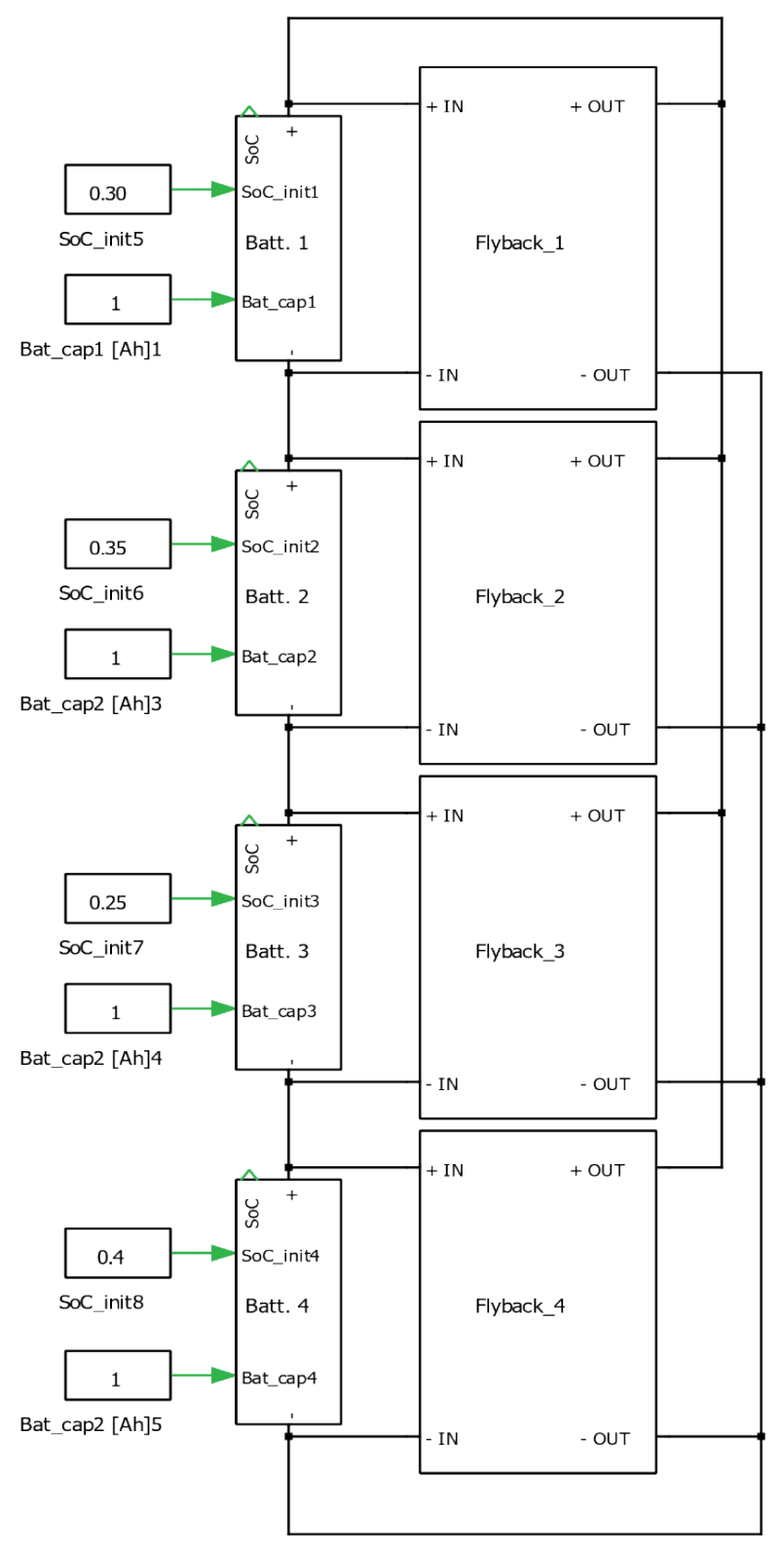

Figure 6 Simulation model of the BMS system with 4 cells

of the flyback converter, which charges the entire battery. Therefore, the current range on the graphs is 40 A. If one increases this value, the efficiency would drop rapidly at this low voltage. Therefore, it is very important to select the value to which these flyback converters will be regulated, in this input current control method. This is a disadvantage of the flyback converter application [11].

The basis of the balancing system and its control is also the same as in the previous 4-cell balancing system. The difference is in the control of the flyback converter. The flyback converters are controlled according to the output voltage value (Figure 3). Figure 8 shows the simulation results and $\mathrm{SoC}$ waveforms, voltages and

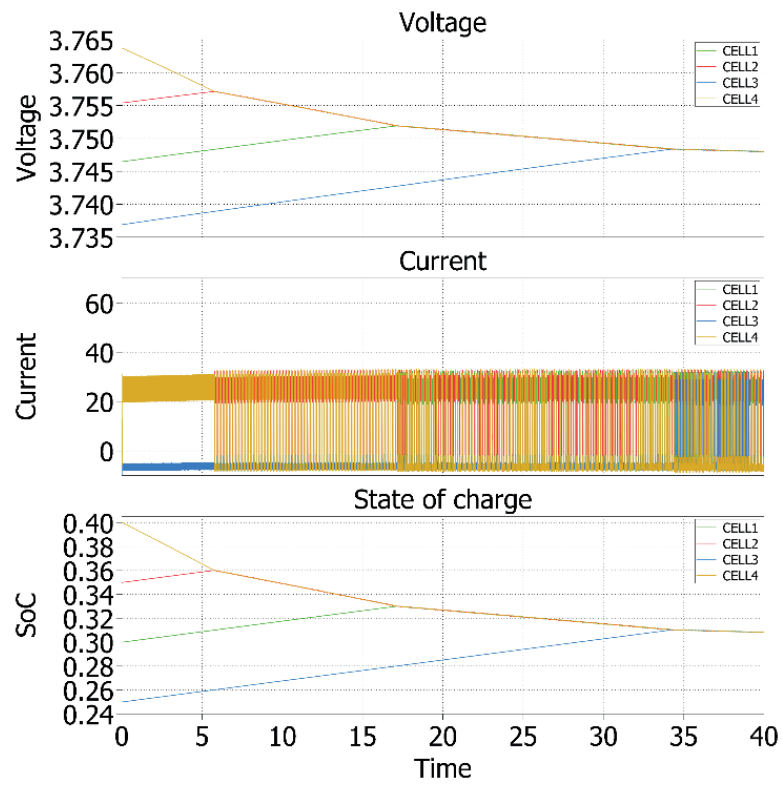

Figure 7 Voltage [V], current [A], state of charge [-] balancing waveform for the 4 cell battery system in terms of time [s]

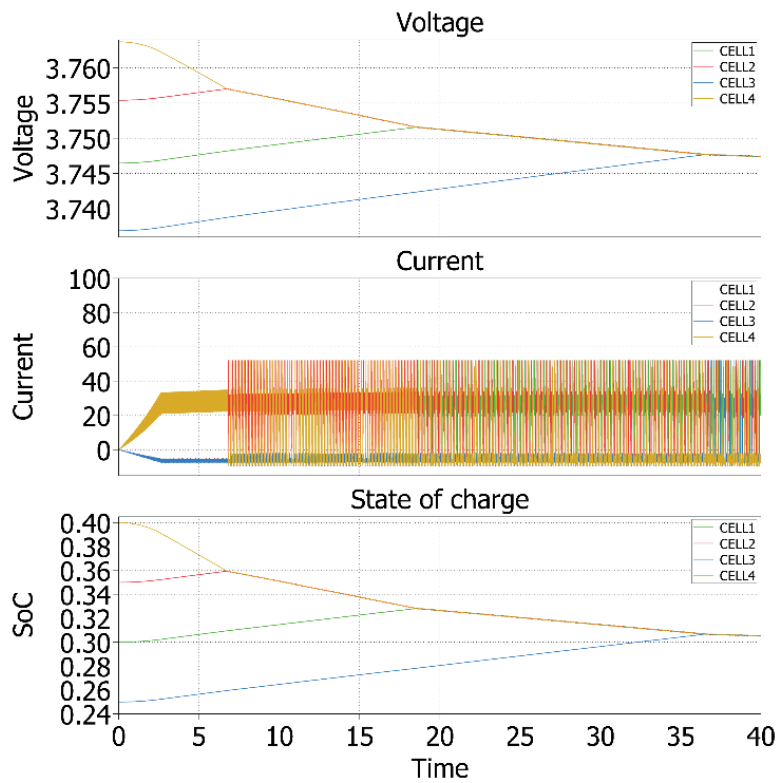

Figure 8 Voltage [V], current [A], state of charge [-] balancing waveform for the 4 cell battery system in time [s]

currents of individual cells. Here one can see that all the cells are balanced in as little as 36 seconds. This is mainly due to the magnitude of the current, which reaches a peak value of nearly $50 \mathrm{~A}$ and the RMS value of nearly $35 \mathrm{~A}$ [11].

\section{Conclusions}

The balancing systems were simulated in this paper. In the first case, the 2 cells were balanced, which had capacities of $1 \mathrm{Ah}$ and SoC of $25 \%$ and $30 \%$ respectively. The capacity was so small only for simulation requirements that the simulation was not so high in the real time. As 
Table 2 The flyback converter parameters for the 4-cell balancing system

\begin{tabular}{cc}
\hline parameter & value \\
\hline input voltage range & $3-4 \mathrm{~V}$ \\
output voltage & $16 \mathrm{~V}$ \\
output nominal current & $7 \mathrm{~A}$ \\
output nominal power & $120 \mathrm{~W}$ \\
switching frequency & $100 \mathrm{kHz}$ \\
required efficiency & $70 \%$ \\
\hline
\end{tabular}

one see in the results of this simulation, the balancing system works.

In the second case, 4 cells were balanced. However, the cell capacities were $1 \mathrm{Ah}$ and $\mathrm{SoC}$ at $25-40 \%$ SoC. The resulting times are therefore as low as these cell capacities were also low. This was set due to the simulation requirements. The main difference in the balancing time of the 4-cell system is in the way of management. In the first case, when the flyback was controlled to the value of the input current, the balancing system immediately took an input current of $30 \mathrm{~A}$. In the second case, when the flyback was controlled to the value of the output voltage, the flyback regulators of the converter had a longer response. As one can see in Figure 8, the current value reaches $30 \mathrm{~A}$ in up to 3 seconds. As a result, this mode is 2 seconds slower than in the case of a flyback converter controlled to the value of the input current.

This method of control consists of finding the maximum value of the SoC. As a result, the more cells are determined on a similar SoC value, the longer it takes to balance the next cell. Therefore, this balancing method is not very suitable for batteries with 8 or more cells.

These simulations were performed due to the skew control of the balancing system and the course of the measured values. Here, it was found that this control is appropriately chosen for both cases. Simulation courses prove it. Further, one can say that the characteristics of the battery replacement scheme and the flyback converter are similar to those of the real applications.

\section{Acknowledgment}

This publication was realized with support of Operational Program Integrated Infrastructure 2014 2020 of the project: Innovative Solutions for Propulsion, Power and Safety Components of Transport Vehicles, code ITMS 313011V334, co-financed by the European Regional Development Fund.

\section{References}

[1] Battery university [online]. Available from: https://batteryuniversity.com/.

[2] PAVELEK, M., SPANIK, P., FRIVALDSKY, M. Voltage stress reduction on compensation capacitors of wireless charging systems for transport and industrial infrastructure. Communications - Scientific Letters of the University of Zilina [online]. 2019, 21(2), p. 50-57. ISSN 1335-4205, eISSN 2585-7878. Available from: https://doi.org/10.26552/com.C.2019.2.50-57

[3] DAOWD, M., OMAR, N., VAN DEN BOSSCHE, P., VAN MIERLO, J. Passive and active battery balancing comparison based on MATLAB simulation. In: 2011 IEEE Vehicle Power and Propulsion Conference: proceedings [online]. IEEE, 2011. ISSN 1938-8756. ISBN 978-1-61284-247-9. Available from: https://doi.org/10.1109/ VPPC.2011.6043010

[4] ADAMEC, J. Research into the possibility of increasing the reliability and safety of energy storage in electric vehicles / Vyskum moznosti zvysovania spolahlivosti a bezpecnosti zasobnikov energie v elektromobiloch (in Slovak). PhD dissertation thesis. Zilina: FEIT-UNIZA, 2019.

[5] BOUKHAL, M. A., LAGRAT, I., ELBANNAY, O. Implementation of a lithium-ion battery state of charge estimation algorithm for BMS on the real time target NI myRio. In: 2019 International Conference on Wireless Technologies, Embedded and Intelligent Systems WITS 2019: proceedings [online]. 2019. p. 1-5. Available from: https://doi.org/10.1109/WITS.2019.8723849

[6] SEN, C., KAR, N. C. Battery pack modeling for the analysis of battery management system of a hybrid electric vehicle. In: IEEE Vehicle Power and Propulsion Conference VPPC'09: proceedings. IEEE, 2009. ISBN 9781424426003, p. 207- 212.

[7] MOGHADDAM, A. F., VAN DEN BOSSCHE, A. An active cell equalization technique for lithium ion batteries based on inductor balancing. In: 9th IEEE International Conference on Mechanical and Aerospace Engineering ICMAE 2018: proceedings [online]. IEEE, 2018. ISBN 978-1-5386-7229-7, p. 274-278. Available from: http:/hdl.handle.net/1854/LU-8572445 
[8] CACCIATO, M., NOBILE, G., SCARCELLA, G., SCELBA, G., SCIACCA, A. G. Energy management optimization in stand-alone power supplies using online estimation of battery SOC. In: 18th European Conference on Power Electronics and Applications EPE'16 ECCE Europe: proceedings [online]. 2016. p. 1-10. Available from: https://doi.org/10.1109/EPE.2016.7695559

[9] FARZAN MOGHADDAM, A., VAN DEN BOSSCHE, A. Flyback converter balancing technique for lithium based batteries. In: 8th International Conference on Modern Circuits and Systems Technologies MOCAST 2019: proceedings. 2019. p. 1-4. Available from: https://doi.org/10.1109/MOCAST.2019.8741893

[10] AIELlO, G., CACCIATO, M., MESSINA, S., TORRISI, M. A High efficiency interleaved PFC front - end converter for EV battery charger. Communications - Scientific Letters of the University of Zilina [online]. 2018, 20(1), p. 86-91. ISSN 1335-4205, eISSN 2585-7878. Available from: http://komunikacie.uniza.sk/index.php/ communications/article/view/52

[11] WANG, Z., LAI, X., WU, Q. A PSR CC/CV flyback converter with accurate CC control and optimized CV regulation strategy. IEEE Transactions on Power Electronics [online]. 2016, 32(9), p. 7045-7055. ISSN 0885-8993. Available from: https://doi.org/10.1109/TPEL.2016.2629846

[12] GALAD, M., SPANIK, P., CACCIATO, M., NOBILE, G., Comparison of common and combined state of charge estimation methods for VRLA batteries. In: 11 $1^{\text {th }}$ International Conference ELEKTRO 2016: proceedings [online]. 2016.p.220 225. Available from: https://dolorg/10.1109/ELEKTRO.2016.7512069

[13] CACCIATO, M., NOBILE, G., SCARCELLA, G., SCELBA, G. Real-time model-based estimation of SOC and SOH for energy storage systems. IEEE Transactions on Power Electronics [online]. 2017, 32(1), p. 794-803. ISSN 0885-8993. Available from: https://doi.org/10.1109/TPEL.2016.2535321

[14] FRIVALDSKY, M., CUNTALA, J., SPANIK, P., KANOVSKY, A. Investigation of thermal effects and lifetime estimation of electrolytic double layer capacitors during repeated charge and discharge cycles in dedicated application. Electrical Engineering [online]. 2018, 100(1), p. 11-25. ISSN 0948-7921, eISSN 1432-0487. Available from: https://doi.org/10.1007/s00202-016-0482-2

[15] KOSCELNIK, J., FRIVALDSKY, M., PRAZENICA, M., MAZGUT, R. A review of multi-elements resonant converters topologies. In: 10th International Conference ELEKTRO 2014: proceedings. 2014. ISBN 9781479937219.

[16] SPANIK, P., CUNTALA, J., FRIVALDSKY, M., DRGONA, P. Investigation of heat transfer of electronic system through utilization of novel computation algorithms. Elektronika Ir Elektrotechnika [online]. 2012, 123(7), p. 31-36. ISSN 1392-1215, eISSN 2029-5731. Available from: https://doi.org/10.5755/j01.eee.123.7.2371

[17] FRIVALDSKY, M., DOBRUCKY, B., SCELBA, G., SPANIK, P., DRGONA, P. Bidirectional step-up/step-down DC-DC converter with magnetically coupled coils. Communications - Scientific Letters of the University of Zilina [online]. 2013, 15(3), p. 21-25. ISSN 1335-4205, eISSN 2585-7878. Available from: http://komunikacie.uniza.sk/ index.php/communications/article/view/682

[18] SPANIK, P., SUL, R., FRIVALDSKY, M. Performance investigation of dynamic characteristics of power semiconductor diodes. Elektronika Ir Elektrotechnika [online]. 2010, 99(3), p. 3-6. ISSN 1392-1215, eISSN 2029-5731. Available from: https://eejournal.ktu.lt/index.php/elt/article/view/9894

[19] DRGONA, P., PRIKOPOVA, A., FRIVALDSKY, M., PRIECINSKY, M. Simulation based method for design and application of digital control system. Communications - Scientific Letters of the University of Zilina [online]. 2011, 13(2A), p. 32-37. ISSN 1335-4205, eISSN 2585-7878. Available from: http://komunikacie.uniza.sk/index. $\mathrm{php} /$ communications/article/view/839

[20] SPANIK, P., FRIVALDSKY, M., DRGONA, P., KANDRAC, J. Efficiency increase of switched mode power supply through optimization of transistor's commutation mode. Elektronika Ir Elektrotechnika [online]. 2010, 105(9), p. 49-52. ISSN 1392-1215, eISSN 2029-5731. Available from: https://eejournal.ktu.lt/index.php/elt/ article/view/9168

[21] D'ANGELO, V., CANNAVACCIUOLO, S., LECCE, S., BENDOTTI, V., PENNISI, O. Enhanced hotplug protection in BMS applications. Part I: Theoretical aspects and practical issues. In: 2019 AEIT International Conference of Electrical and Electronic Technologies for Automotive AEIT Automotive 2019: proceedings [online]. 2019. p. 1-5. Available from: https://doi.org/10.23919/EETA.2019.8804513 